\title{
Apoptosis in the rat mammary gland and ventral prostate: detection of cell death-associated genes using a coincident- expression cloning approach
}

\author{
Wolfgang Bielke ${ }^{1,2}$, Guo $\mathrm{Ke}^{1}$, Zhiwei Feng ${ }^{1}$, Susanne \\ Buhrer ${ }^{1}$, Susanne Saurer ${ }^{1}$ and Robert R. Friis ${ }^{1,3}$ \\ ${ }^{1}$ Laboratory for Clinical and Experimental Research, University of Berne, \\ Tiefenaustrasse 120, CH-3004 Bern, Switzerland \\ 2 Present address: Department of Veterinary and Animal Sciences, University of \\ Massachusetts, Amherst, Mass. USA \\ 3 corresponding author: tel: 0041-31-308-8011, fax: 0041-31-308-8028; \\ e-mail: friis@akef.unibe.ch
}

Received 22.7.96; revised 2.9.96; accepted 3.9.96

Edited by B.A. Osborne

\begin{abstract}
Apoptosis plays a striking role in the hormone-dependent involution of the mammary gland, but it has proved difficult to distinguish between the 'cell death' associated genes and the 'tissue remodelling' genes which are expressed concurrently. To identify cell death-associated genes, we have established a 'coincidence analysis', based on the previously described 'RNA differential display' method of Liang and Pardee (1992). Coincidence analysis allows the detection of genes expressed during related processes in different organs and was employed here to identify transcripts in which expression patterns are seen to be associated with apoptosis during involution of both rat mammary- and the ventral prostate glands. That the coincidence analysis is a promising approach can be seen from the fact that while widely accepted apoptosis markers such as transglutaminase (Fesus et al, 1987; Strange et al, 1992) and sulfated glycoprotein-2 (Buttyan et al, 1989; Strange et al, 1992; Guenette et al, 1994) exhibited similar expression in both regressing tissues, transcription of tissue remodelling enzymes was minimal in the involuting prostate.

We describe here the characteristics of five clones isolated which show coincident expression during programmed cell death in mammary and prostate tissues. Partial sequence analysis revealed for three clones high homologies with previously described genes; the putative rat homolog of the growth arrest gene gas-1 (Schneider et al, 1988; Del Sal et al, 1992), a homolog of the mouse 'Integrin Associated Protein' (IAP) (Brown etal, 1990; Lindberg et al, 1993) and the sequence encoding for the 'Allograft Inflammatory Factor' AIF-1 (Autieri et al, 1995; Utans et al, 1995). One clone displayed homology with an expressed human sequence tag and one clone unrelated to any known DNA sequence was isolated. The expression of these genes in involuting rat mammary and ventral prostate, was correlated with that in other organs and
\end{abstract}

in situ hybridization was applied to establish that the secretory epithelial cells which undergo programmed cell death are the site of elevated expression during the course of involution. Furthermore, we conclude that the coincidence analysis approach described here could be easily applied to facilitate the characterization of gene expression i.e. for the detection and comparison of hormonally regulated genes in different organs.

Keywords: apoptosis, cell death, mammary gland, prostate, differential display

Abbreviations: TNF, tumour necrosis factor; PCD, programmed cell death; ICE, interleukin- $1 \beta$-converting enzyme; DDC, differential display coincidence analysis; dCTP, deoxycytosine triphosphate; SGP-2, sulphate glycoprotein 2; TGF$\beta 1$, transforming growth factor $\beta 1$; tTG, tissue transglutaminase; tPA, tissue plasminogen activator; SDS, sodium dodecylphosphate; dUTP, deoxyuridine triphosphate, uro.PA, urokinase plasminogen activator; TIMP, tissue inhibitor of metallo proteinases; AIF-1, allograft inflammatory factor; IAP, integrin associated protein; $\mathrm{HU}$, hydroxy urea

\section{Introduction}

The control of physiological functions and the fate of an organ often require the elimination of harmful or unnecessary cells, which is, in most cases, dependent on defined conditions and predictable in its consequences. One mechanism by which this programmed cell death (PCD) (Lockshin and Williams, 1964) occurs is apoptosis (Kerr et al, 1972), a morphologically and biochemically defined event. Apoptosis in its classical form involves a cell-autonomous suicide program often requiring de novo RNA and protein synthesis leading to the elimination of the affected cells in a non-necrotic process without inflammatory reaction (Wyllie et al, 1980). The mechanisms, by which the onset of apoptosis is triggered are under active investigation. Nevertheless, some mediators of apoptotic processes in mammalian cells can already be defined at various physiological levels. Important regulators of apoptosis include the Fas-mediated signal-transduction by a TNF-related ligand (Trauth et al, 1989; Itoh et al, 1991; Suda et al, 1993), and transcription factors as the orphan steroid receptor Nur77 (Liu et al, 1994; Woronicz et al, 1994; Jehn and Osborne, 1997). Apoptosis can also occur endogenously as a response to genomic instability involving p53, a tumor suppressor-protein with transcription factor activity (for reviews see Donehower and Bradley, 1993; Nelson and Kastan, 1994). Accumulation of p53-protein causes arrest in the G1-phase of the cell-cycle (Kuerbitz et al, 1992; Lin et al, 
1992) which may be followed by subsequent apoptosis (Yonish-Rouach et al, 1991; Shaw et al, 1992; Ryan et al, 1993). Genes which are transcriptionally induced by binding of the p53-protein to a promoter-element include Waf1/Cip1 (El-Deiry et al, 1993; Harper et al, 1993) and GADD45 (Kastan et al, 1992), both of which participate in the p53-dependent growth arrest, as well as the $b c /-2$ homolog bax (Miyashita and Reed, 1995). Furthermore, apoptotic processes are often accompanied or even caused by changes in intracellular physiological conditions, i.e. a sharp increase in $\mathrm{Ca}^{2+}$-ion concentration (McConkey et al, 1989). Importantly, several evolutionarily conserved genes, exemplified by the Cenorhabditis elegans gene ced-3 and members of the mammalian interleukin-1 $\beta$-converting enzyme family (ICE), have been shown recently to regulate programmed cell death processes (Miura et al, 1993; Yuan et al, 1993; Kumar et al, 1994; Wang et al, 1994).

Hormone dependent apoptosis of secretory epithelial cells can be observed in the involuting mammary gland after weaning (Walker et al, 1989; Strange et al, 1992) and in the ventral prostate following castration (Kerr and Searle, 1973; for review see Tenniswood et al, 1992). The mammary gland is a tubuloalveolar organ undergoing repetitive postembryonic differentiation steps between quiescent- and an active, milk-secreting stage. During pregnancy, the ductal epithelial components of the gland grow out and branch into the surrounding stromal tissue, leading finally to the lactating organ. Throughout involution, a dramatic decrease in number of the secretory epithelial cells occurs by apoptosis within a few days after weaning and is accompanied by dramatic tissue remodelling and the proteolytic resolution of the basal lamina, leading ultimately to the reestablishment of the quiescent, fat and stromal tissue dominated organ (Warburton et al, 1982; Daniel and Silberstein, 1987; Pitelka, 1988; Walker et al, 1989). The involution process of the mammary gland can be considered as being divided into two parallel occurring events: Firstly, tissue remodelling requiring the coordinated action of various metalloproteases and their inhibitors, as well as the activation of mechanisms leading to the reconstitution of stromal components and secondly, the elimination of the secretory epithelial cells by apoptosis in association with the stimulation of cell-autonomous processes, such as protein kinase A-activity and the transcription of certain genes already recognized as being involved in apoptotic processes in other cell types (Dickson and Warburton, 1992; Strange et al, 1992; Talhouk et al, 1992; Li et al, 1995; Marti et al, 1994; Lund et al, 1996). Most involution associated genes characterized so far seem to be involved in the tissue remodelling, rather than being functionally related to apoptosis. This is reflected by the relative abundance of transcripts in the involuting mammary gland as coding for remodelling proteins. Therefore, more subtle techniques have been needed to detect those less abundant transcripts which are likely to be involved in the apoptotic process itself.

In the rat ventral prostate, another organ where PCD has been extensively studied, apoptosis of the glandular epithelial cells can be experimentally induced by castration. The regressing ventral prostate shows several morphological and biochemical features of apoptosis analogous to the involuting mammary gland (Kerr and Searle, 1973). We demonstrate here that several features are apoptosis-associated indistinguishable in prostate and mammary glands, following much the same time-course. On the other hand, tissue remodelling in the regressing prostate was much less evident, as it is shown by strikingly different transcription patterns of major tissue remodelling enzymes. The coincident expression of a gene during both mammary and prostate involution points, therefore, rather to an apoptosis-associated process as distinct from tissue remodelling. To identify such genes, which are more likely to participate directly in apoptosis, we compared RNAs from several involution stages of rat mammary and prostate glands in parallel using the 'Differential Display'-Assay (Liang and Pardee, 1992). Only fragments showing a comparable regulation were chosen for further analysis. We designate this novel application a 'Differential Display Coincidence Analysis' (DDC) and describe the characteristics of the several genes identified, which show coincident regulation during involution of the two hormone-dependent glandular tissues.

\section{Results}

\section{Mammary and prostate glands show a similar hormone ablation-induced PCD, but differ in tissue remodelling}

No DNA-fragmentation was detected in the normal ventral prostate using an in situ DNA fragmentation assay (Gavrieli et al, 1992), but by $60 \mathrm{~h}$ after castration, stained nuclei in the assay indicate the incorporation of labeled nucleotides to free 3 ' DNA-ends generated by the endonucleolytic activity typical of apoptosis (data not shown).

Using the regressing prostate as an additional model for apoptosis, we examined the expression of two classes of appropriate marker genes in the involuting rat prostate: genes whose specific expression patterns are closely related with apoptotic events in general (Figure 1a) and tissue remodelling markers, i.e. various proteases (Figure 1b). Compared with analogous gene expression in the involuting mammary gland (Strange et al, 1992), a notable lack of tissue remodelling response is evident in the regressing prostate. The $72 \mathrm{kD}$ gelatinase which is sharply upregulated in mammary gland tissue, shows no change above the basal level in the prostate. Contrary to the involuting mammary gland, stromelysin-RNA was undetectable in the regressing prostate, as was tissue plasminogen activator (tPA). Urokinase plasminogen activator (uro.PA) which was not significantly up-regulated in mammary gland involution, was weakly expressed and slightly elevated when compared to the normal prostate. Not surprisingly, levels of the tissue inhibitor of metalloproteinases (TIMP)message were low until day 6 of prostate involution, when a modest elevation could be detected (data not shown).

Regarding apoptosis markers, expression patterns in the involuting prostate were comparable with the mammary gland (see Strange et al, 1992). Sulphated glycoprotein-2 (SGP-2)-transcription is dramatically increased at day 2 of 
involution as it is also in the mammary gland, declining by day 6 post-castration. As in mammary gland involution, elevated expression of tissue transglutaminase (TG) is slow, with a peak at day 6 post castration. p53 gene and transforming growth factor- $\beta 1$ (TGF- $\beta 1$ ) gene expression rise similarly in involuting prostate and mammary gland, showing maxima at 2 days and 4 days post-castration, respectively.

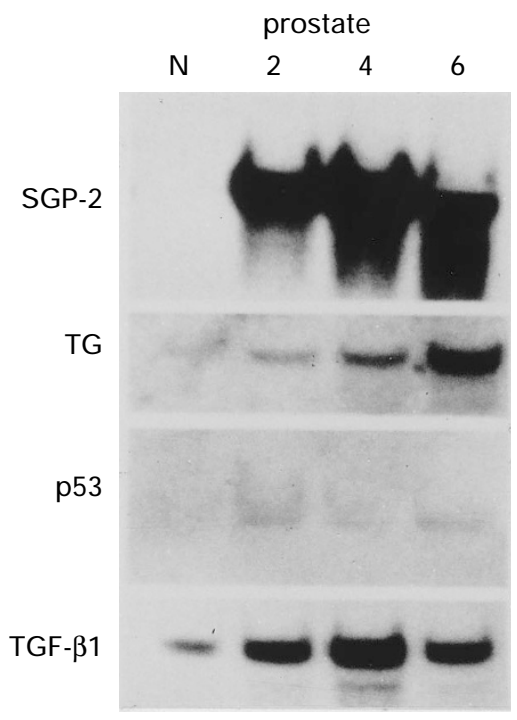

b

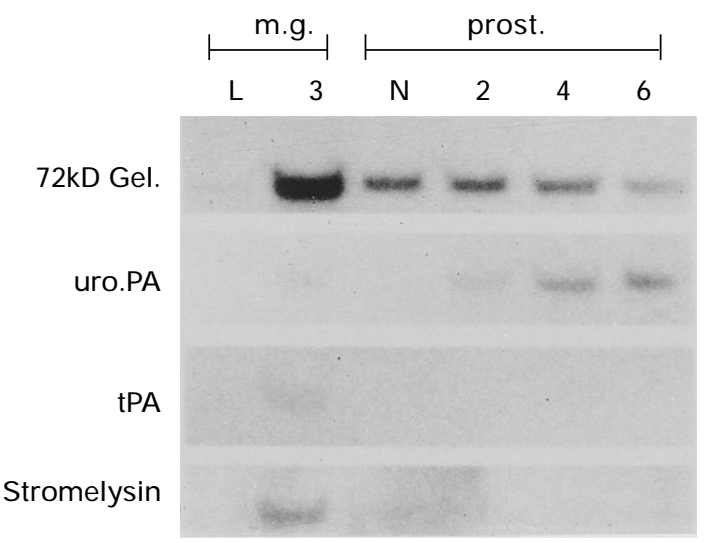

Figure 1 Apoptosis (a) and tissue remodelling (b) markers. PolyA(+) RNA samples $(5 \mu \mathrm{g} / \mathrm{lane})$ from the rat ventral prostate $(\mathrm{N})$ and at days following castration $(2,4,6)$ were examined in Northern blots for expression of genes encoding several widely accepted apoptosis markers and for enzymes known to be important for tissue remodelling in rodent mammary glands. $L$ indicates PolyA(+) RNA from lactating rat mammary glands and 3 indicates $\mathrm{PolyA}(+)$ RNA from mammary glands, 3 days after weaning. Abbreviations are: SGP-2, sulphated glycoprotein-2; TG, tissue transglutaminase; p53, p53 suppressor gene, TGF- $\beta 1$, transforming growth factor $\beta 1 ; 72 \mathrm{kD}$ Gel., $72 \mathrm{kD}$ gelatinase, uro. PA, urokinase plasminogen activator, tPA, tissue plasminogen activator stromelysin; (for regulation of these genes during mammary gland involution, see Strange et al, 1992).

\section{Identification and cloning fragments of regulated genes}

Several combinations of the $3^{\prime}$-primers $T_{12} M C$, or $T_{12} M G$ and 10 different 5 '-primers were used for the Differential Display PCR-reactions. Individual reactions were loaded onto denaturing polyacrylamide-gels (Figure 2). As expected, most PCR-fragments were detectable in all developmental stages of each gland after their separation over polyacrylamide-gels. Many other fragments were present in varying combinations, but failed to reveal a

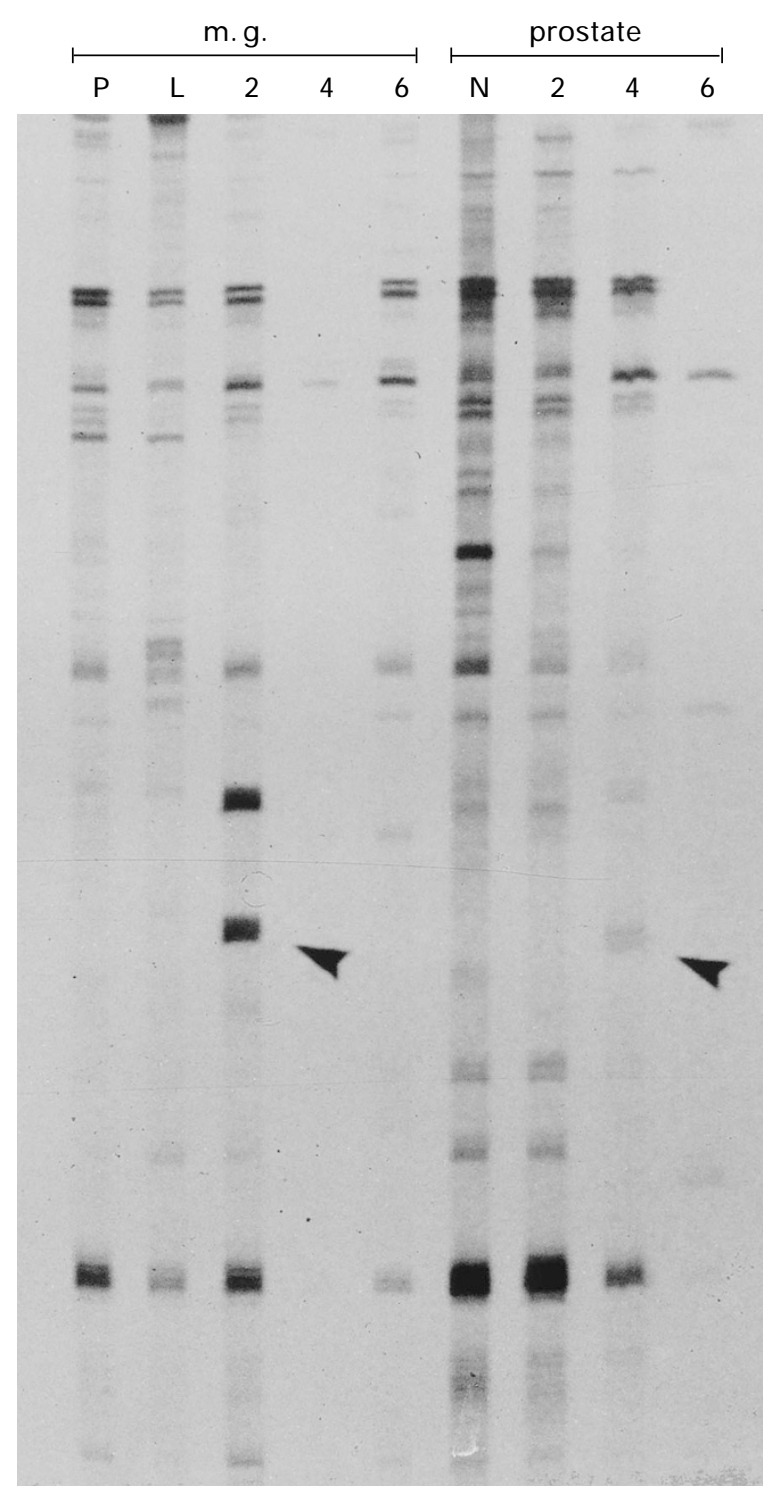

Figure 2 Differential Display of RNAs derived from various mammary and ventral prostate gland stages before and after involution. $0.2 \mu \mathrm{g}$ total RNA from each sample were used for PCR-amplification in a 'Differential Display' Assay (Liang and Pardee, 1992). Amplified fragments were separated over a $6 \%$ denaturing polyacrylamide-gel. Mammary gland samples derived from pregnant $(P)$, Lactating $(L)$ and from 2, 4 and 6 days post-weaning tissues. Prostate samples were Normal (V), 2, 4 and 6 days after castration. The arrow indicates the bands which led to the identification of clone DDC-2. 
coincidence pattern. Relatively rare cases manifested a coincident expression pattern elevated in both involuting mammary gland and prostate. These were chosen for excision from the Differential Display gels. We isolated preferentially fragments displaying the strongest signal at approximately day 3 of involution in both glands. An example is indicated in Figure 2 and led to the identification of clone DDC-2. The size of the isolates ranged between 350 and 500 base-pairs. Successfully reamplified PCR-fragments from 12 reactions were used for blunt-end cloning into the Bluescript plasmid (Stratagene) and were used for further analysis. Table 1 indicates the primer combinations, from which the isolates derived.

\section{Expression patterns and sequence analysis of DDC-clones during rat mammary gland and prostate involution}

After successful subcloning 12 PCR-fragments, single clones were used as probes for Northern analysis. Five $\mu \mathrm{g}$ poly $\mathrm{A}(+)-$ enriched RNA-samples from various developmental stages of the mammary gland and the ventral prostate were used as shown in Figure 3. Of the 12 PCR-fragments initially used for cloning, five presented a coincident regulation during mammary gland and ventral prostate involution as expected and were named DDC-1 to DDC-5 (Figure 3). Two further fragments showed a wide range of hybridization signals on Northern blots, typical for sequences containing repetitive elements. The remaining probes either failed to reveal any detectable signal on Northern blots or were false positives. Expression of DDC-homologous transcripts was in general low during all stages other than involution, with the exception of clone DDC-2 (Figure 3), which is relatively strongly expressed in the mammary gland of pregnant animals. Signals were markedly increased with a peak around day three of involution. The two day involution point immediately preceeds the onset of cell death, while day three corresponds to the stage where most of the epithelial cells show DNA fragmentation in both glands. In the prostate and partly in the mammary gland, the signals either decrease in their intensity with time (eg. clones DDC-1 and DDC-5) or show a second peak at a later time point (e.g. clone DDC-3). Notably, with DDC-4, no expression was detected at any pre-involution stage in the mammary gland. In the case of DDC-2 and DDC4 , probes reproducibly detected multiple transcripts.

Table 1

\begin{tabular}{lll}
\hline $\mathbf{3}^{\prime}$ Primer & 5' $^{\prime}$ Primer & Clones Identified \\
\hline $\mathrm{t}_{12} \mathrm{MC}$ & 5'-AGCCAGCGAA-3' $^{\prime}$ & DDC-1; DDC-2 \\
& 5'-CCGAAGGAAT-3' $^{\prime}$ NDN-2 \\
& 5'-TAGCAAGTGC-3' & DDC-3'; DDC-4, FP-3; FP-4 \\
$\mathrm{T}_{12} \mathrm{MG}$ & 5'-GACCGCTTGT-3' & FP-1; FP-5; REP-1 \\
& 5'-AGGTGACCGT-3' & REP-2 \\
& 5'-GGTACTCCAC-3' & DDC-5; FP-2; NDN-1 \\
\hline
\end{tabular}

Combinations of Dierential Display PCR-primers which were used for the amplification of clones are indicated. The primer-sequences are according to GenHunter Corporation. M indicates a degenerate position, consisting either of $\mathrm{G}, \mathrm{C}$ or $\mathrm{A}$

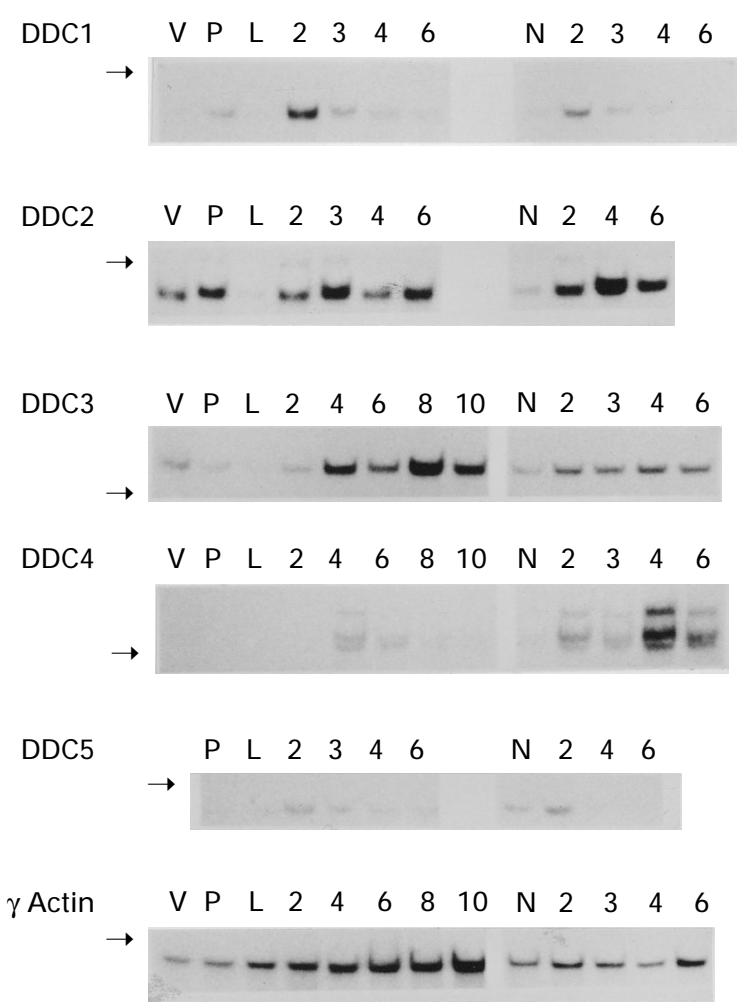

Figure 3 Northern blot analysis of DDC-clones. Northern blots were performed on $5 \mu \mathrm{g}$ polyA RNA per sample from the rat mammary gland (virgin $(\mathrm{V})$, pregnant $(\mathrm{P})$, lactating $(\mathrm{L})$, and involuting at different days after forced weaning), or from rat ventral prostate gland (normal $(\mathrm{N})$ and different days following castration). The location of the $18 \mathrm{~S}$ RNA-band is indicated by an arrow.

\section{Sequence analysis of the DDC clones}

Sequence analysis revealed in four DDC fragments homologies of various degrees with sequences previously described in other species and in different contexts. DDC-1 revealed ca. $86 \%$ homology at the nucleic acid level within the coding region of the murine Integrin Associated Protein $(I A P)$ gene (Lindberg et al, 1993). DDC-2 represents a region from the transcript encoding the Allograft Inflammatory Factor (AIF1) (Autieri et al, 1995; Utans et al, 1995), whereas DDC-3 displays a ca. $90 \%$ homology with sequences near the 3 '-end of the mouse gas- 1 gene (Del Sal et al, 1992). DDC-5 displays ca. $80 \%$ homology with a human expressed sequence tag (Genebank-database No. humgs 01767), and DDC-4 did not reveal significant homologies with any sequences in the EMBL or Genebank-databases.

\section{Expression of DDC clones in different tissues}

The relative expression of the different DDCs in various organs and tissues is indicated in Figure 4a. Unsurprisingly, the various DDC genes are expressed in other organs than mammary gland or prostate. Closer analysis shows, however, that for DDC 1,2,3 and 4, expression is highest in organs likely to be participating in programmed cell death. DDC 4 expression is limited to potentially involuting organs such as mammary gland, prostate, uterus and ovary. Since the tissue RNA samples were prepared from pools of $2-4$ animals each 
a
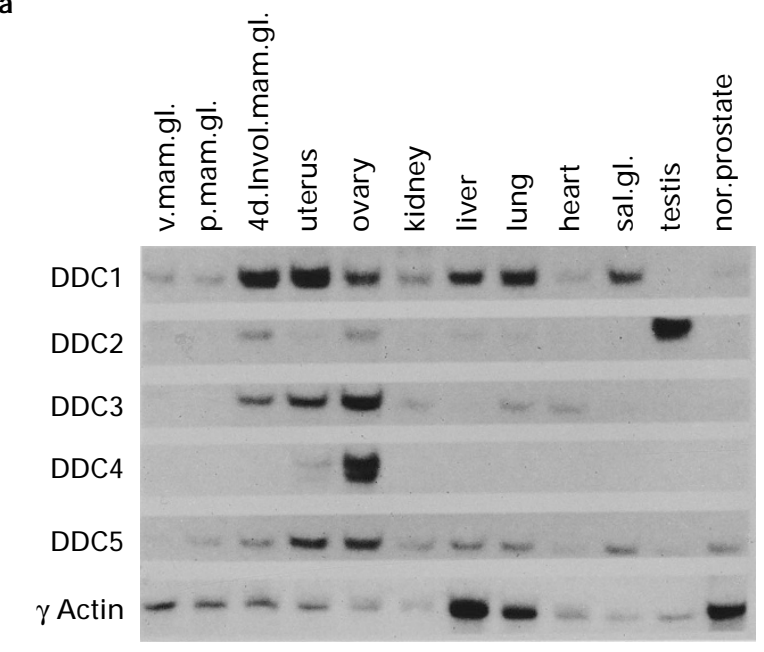

b

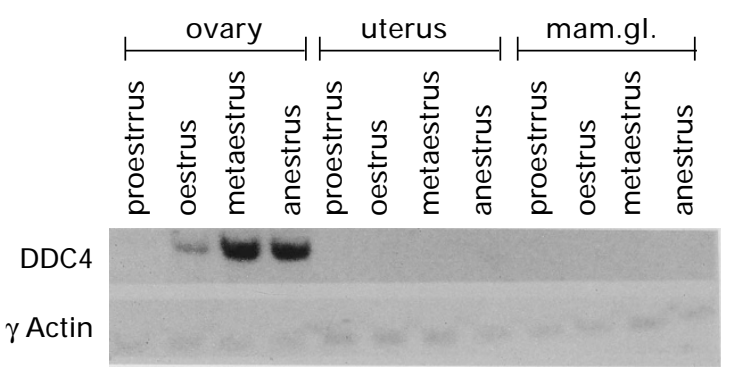

Figure 4 Northern blot analysis of DDCs in different tissues. Northern blots were performed as described on polyA RNA samples from different organs as indicated (a). For ovary, uterus and mammary gland (b) RNAs were prepared from organs at different stages of oestrus. Clones (DDC) were a) DDC-1, IAPhomolog; b) DDC-2, AIF-1 homolog; c) DDC-3, gas-1 homolog; d) DDC-4; e) DDC-5. Note that the weakness of the DDC-4 signal during the different oestrus stages of the uterus (b) is due to the relative longer exposure of blot $4(a)$, representing the various organs derived from pools of animals.

it was likely, for example, that different oestrus stages were represented. Hence, an experiment was performed (Figure $4 b$ ) in which ovarian, uterine and mammary gland mRNA was prepared at defined oestrus stages. These data show a strong correlation with oestrus for DDC-4 expression suggesting a role restricted to programmed cell death. The exposure in Figure $4 \mathrm{~b}$ was performed to allow reasonable quantitation for ovarian RNA samples and allows only a faint recognition of a positive signal in uterus under these conditions and none at all in mammary gland, even after longer exposure times.

\section{Expression of DDC-1 (IAP) and DDC-3 (gas-1) occurs in the mammary secretory epithelial cells which undergo programmed cell death}

In situ hybridization was employed to visualize the cells showing increased $D D C-1$ and $D D C$-3 expression during the course of mammary involution. The alkaline phosphatase detection method allows the unambiguous recognition of the expressing cell. It is abundantly clear, that for $D D C-1$, the mammary secretory layer exposed to the alveolar lumen shows a widespread positive reaction with the antisense
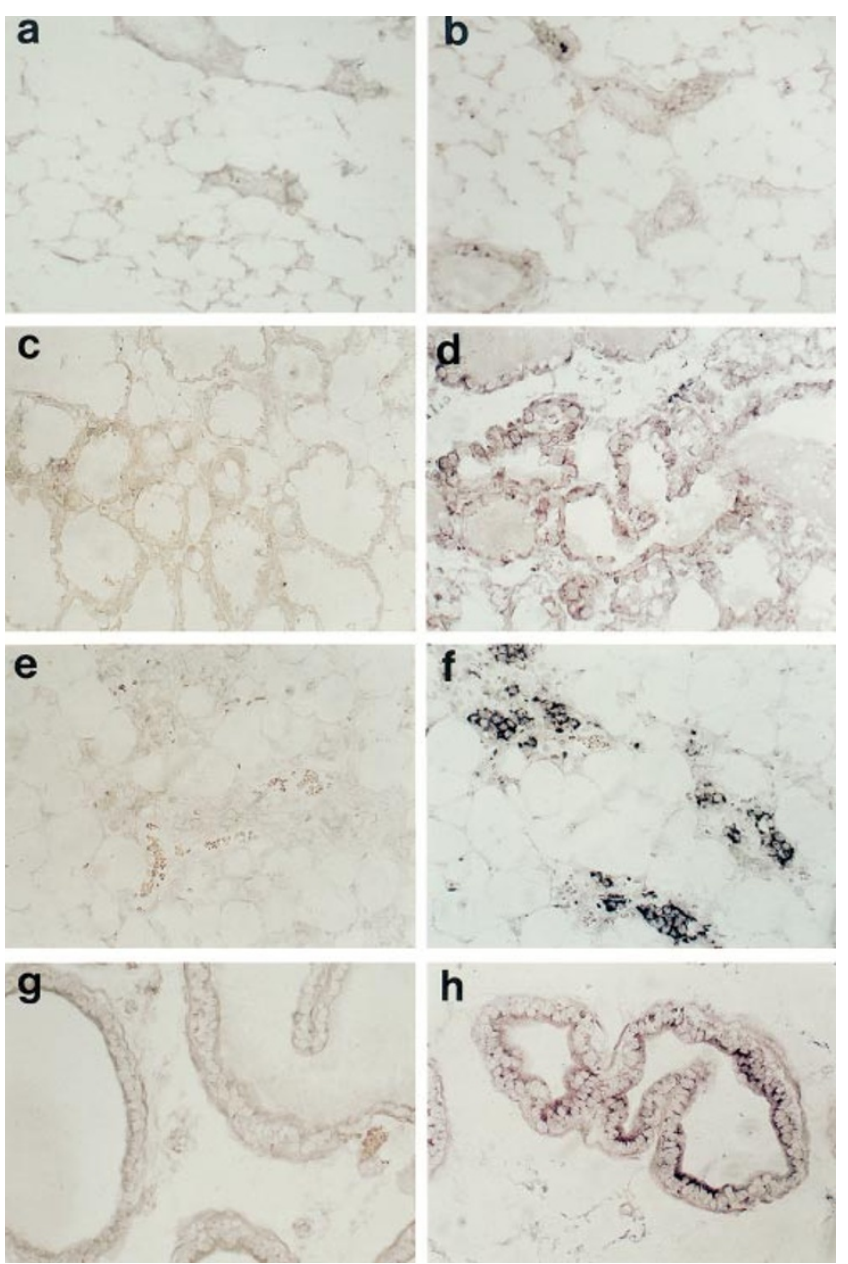

Figure 5 In situ hybridization with FITC-labeled riboprobe was employed to demonstrate DDC-1 expressing cells: ( $\mathbf{a}$ and $\mathbf{b})$ sections from 16 day pregnant mammary gland, (c and $\mathbf{d}$ ) sections from 2 day involuting mammary gland (e and $\mathbf{f}$ ) sections from 4 day involuting mammary gland and ( $\mathbf{g}$ and $\mathbf{h}$ ) ventral prostate 3 days after castration. Sections were hybridized with probes as follows: $\mathbf{a}, \mathbf{c}, \mathbf{e}$ and $\mathbf{g}$ were hybridized with a DDC-1 sense probe, while $\mathbf{b}, \mathbf{d}, \mathbf{f}$ and $\mathbf{h}$ were hybridized with antisense probe.

probe by 2 days (Figure $5 d$ ) which is increased by 4 days (Figure 5f) postlactation. This reaction is absent either with the sense probe tested on parallel sections, or very low with antisense probe-treated sections of pregnant mammary gland (Figure 5b). When compared with the Northern blot in Figure 3 , it is notable that the apparently stronger signals at day 4 are detected in relative small clusters after the breakdown of the tissue structure and that this result does not reflect the overall transcript content of the organ. Stromal tissue regions are uniformly negative. Myoepithelial cells seem to be negative, but the morphology does not allow them to be conclusively identified. Sections of rat ventral prostate were analyzed, showing a negative reaction on normal tissue, and a clear reaction product by 3 days after castration (Figure $5 \mathrm{~h}$ ).

For the $D D C-3$ antisense probe, a similar reactivity could be demonstrated (Figure 6) though developing with slower kinetics. With $D D C-3$, the positive signal is essentially 
visible only after the full collapse of the alveolar structures, obviously consisting of mainly apoptotic cells.

\section{Gas-1 fails to block immediately in the $G_{1}$ stage of cell cycle}

In considering the possible role of gas-1 in apoptosis, the anology to p53 comes to mind. We performed an experiment, therefore, to examine the possibility that gas-1 imposes a block in transition out of $\mathrm{G}_{1}$ into the S-phase of the cell cycle. Figure 7a shows that in Balb/c 3T3 cells, the expression of gas-1 is serum dependent, declining sharply within $2 \mathrm{~h}$ after serum is added to quiescent, serum-starved cells grown to confluency. Furthermore, in a different experiment, where serum is removed from confluent cultures, the gas- 1 induction is sensitive to a cycloheximide or emetine block in protein synthesis imposed at the same time as serum removal (Figure 7b).

An experiment in which hydroxy urea (HU) blocked entry of freshly trypsinized cells into the S-phase of the cell cycle was employed to show that even cells which have already induced a relatively high gas-1 expression (Figure 7c) under $\mathrm{HU}$ inhibition, nonetheless enter the cell cycle promptly after the inhibitor is washed out (Figure 7d). Figure 7d shows the plotted results of counts of per cent individual cells incorporating $\left[{ }^{3} \mathrm{H}\right]$ thymidine in a $1 \mathrm{~h}$ label as demonstrated using autoradiography and employing parallel cell cultures to those in Figure 7c. These data indicate that the presence of even relatively high levels of gas-1 expression does not prevent transition from pre-existing late $G_{1}$ phase into the $S$ phase of cell cycle.

\section{Discussion}

\section{Differential Display Coincidence Analysis (DDC) facilitates the detection of genes involved in related physiological processes}

Apoptosis is a multistep process and requires the concerted action of different proteins. Previous studies have revealed numerous genes which are differentially expressed during involution of the mammary gland (Strange et al, 1992; Talhouk et al, 1992), several of them being associated with apoptosis in other tissues. Differential screening protocols led to the identification of further genes regulated during mammary gland involution (Bielke et al, 1995; Li et al, 1995), some of them represented previously unknown sequences. Since transcripts encoding tissue remodelling proteins are relatively abundant during involution of the mammary gland, they may mask important RNAs from 'cell death genes', present at lower levels. To overcome this limitation and to identify genes which are more likely to be
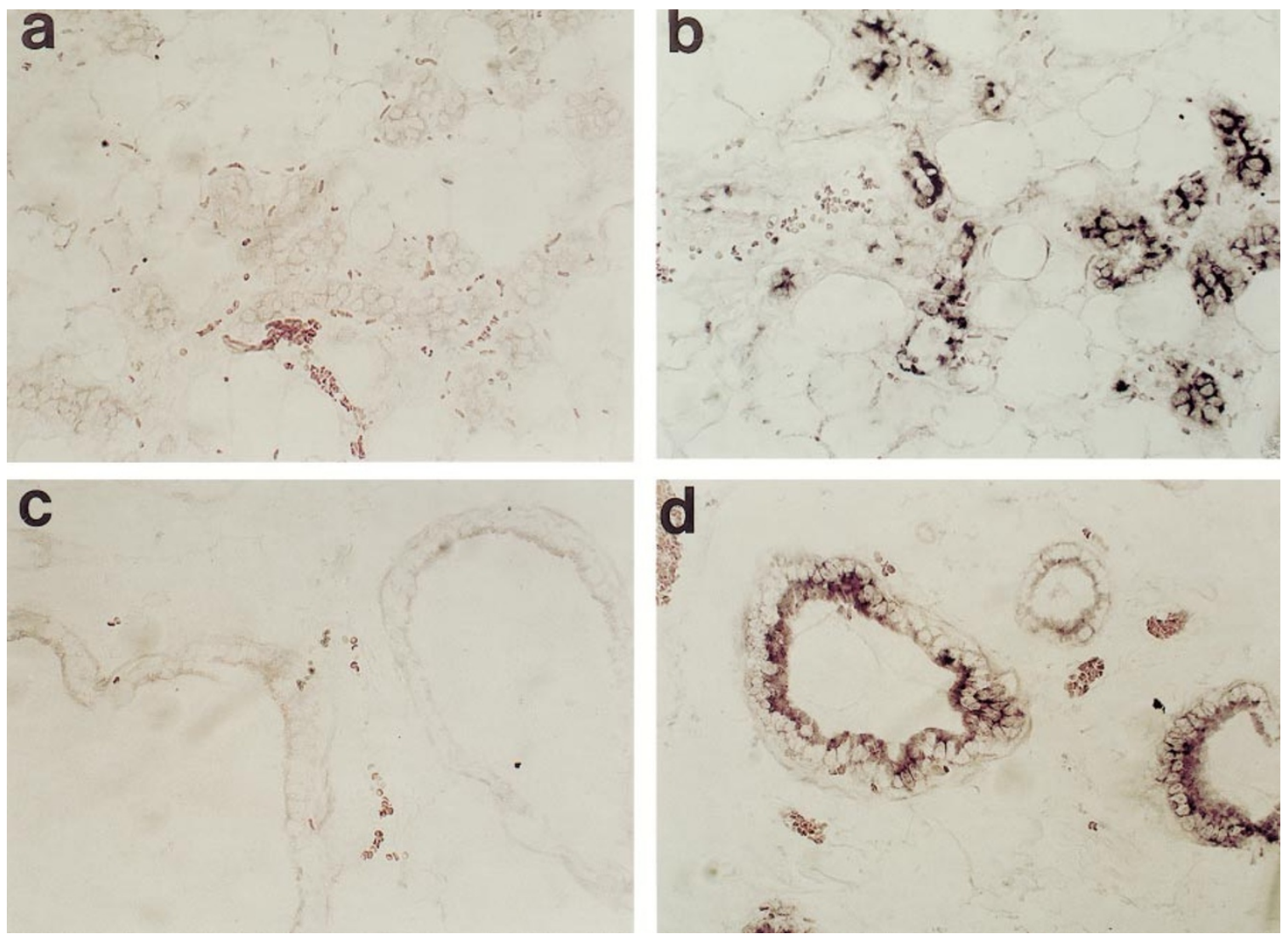

Figure 6 In situ hybridization with FITC-labeled riboprobe indicates the localization of DDC-3 expression ( $\mathbf{a}$ and $\mathbf{b}$ ) sections from 4 day involuting mammary gland; (c and $\mathbf{d}$ ) sections from ventral prostate 3 days after castration. Sections were hybridized with the following: a and $\mathbf{c}$ were hybridized with DDC-3 sense probe, while $\mathbf{b}$ and $\mathbf{d}$ were hybridized with antisense probe. 
important for apoptosis, we used the regressing prostate as a second model in comparison to study apoptosis-associated gene-regulation. To gain evidence for our hypothesis that

a

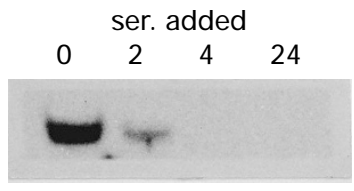

b

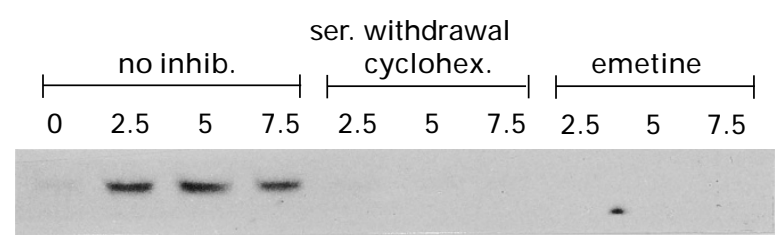

C

$\begin{array}{ccccccl}- & + & - & - & + & - & \text { HU } \\ 10 & 0.5 & 0.5 & 10 & 0.5 & 0.5 & \% \text { ser } \\ 22 & 22 & 22 & 24 & 24 & 24 & \text { hrs. }\end{array}$

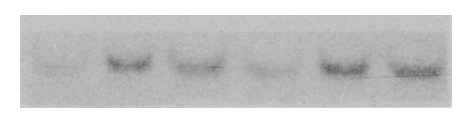

d

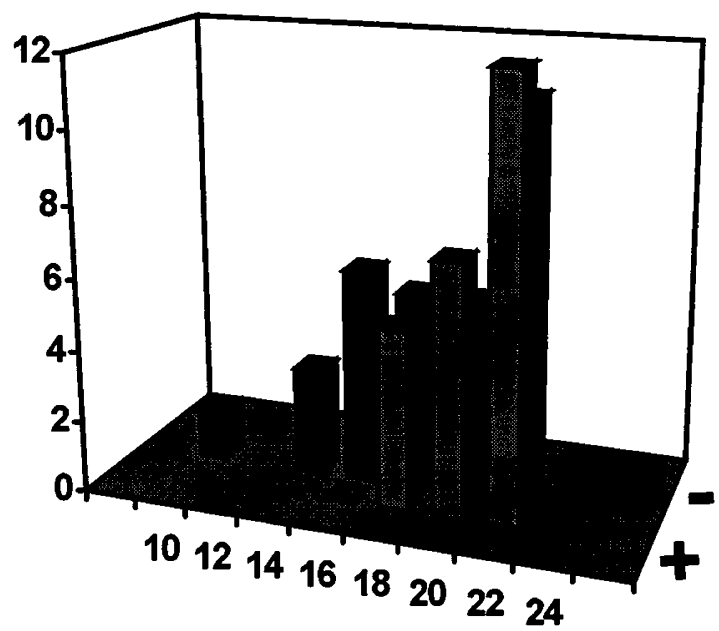

Figure 7 Northern blot of DDC-3 (gas-1) expression in cell cycle. (a). A Northern blot shows the response to addition of $10 \%$ fetal calf serum to a confluent culture ofBalb/c 3T3 cells. (b) Removal of serum was performed with the same type of cell in log culture, showing a sensitivity to cycloheximide $(10 \mu \mathrm{g} / \mathrm{ml})$ inhibition and emetine $(50 \mu \mathrm{g} / \mathrm{ml})$. (c). Hydroxyurea was used to provide a delayed entry into $S$ phase of freshly trypsinized Balb/c 3T3 cells and kinetics of DDC-3 expression (c) and DNA synthesis (d) were compared in hydroxyurea treated and untreated cells at different times. The HU block was initiated $10 \mathrm{~h}$ after trypsinization and released at $16 \mathrm{~h}$. The $\mathrm{x}$-axis represents time in hours, whereas the $y$-axis is indicating the percentage of cells incorporating $\left[{ }^{3} \mathrm{H}\right]$-thymidine. tissue remodelling during prostate regression is only involved at a minor level, but that apoptosis is as significant as in the mammary gland, we have chosen two classes of probes for Northern blot analysis. The first class consisted of cDNAs from several tissue-remodelling genes, important during mammary gland involution; the second class included fragments ubiquitously associated with apoptosis. The detection of identical expression patterns of individual genes during the regression of both glands should argue therefore rather for a role in apoptosis, but not in the tissue remodelling process. We describe remarkable differences found between prostate and mammary gland regression when using the markers for tissue-remodelling (compare Figure $1 \mathrm{~b}$ and Strange et al, 1992). On the other hand, several events known to be associated with programmed cell death in various other tissues, such as the endonucleolytic DNA-fragmentation (Wyllie, 1980), the rapid increase of SGP-2 transcription (Buttyan et al, 1989; Jenne and Tschopp, 1992) and the regulation patterns of transglutaminase (Fesus et al, 1987) and TGF- $\beta 1$ (Martikianen et al, 1990; Rotello et al, 1991) were comparable during involution in both glands (Figure 2a; for comparison see Strange et al, 1992; Li et al, 1995). Morphological differences between apoptosis in the mammary gland and the ventral prostate have been discussed earlier (Tenniswood et al, 1992). Our results support the idea that tissue remodelling in the prostate is less evident than in the regressing mammary gland and that similar expression patterns of genes should argue for an analogy to apoptosis.

Several strategies exist for identifying differentially expressed genes either in different cell types or in different developmental- or differentiation-stages (Schwartz et al, 1995). Commonly used protocols include differential screening (St John and Davis, 1979; Williams and Lloyd, 1979) and subtraction strategies (Zimmermann et al, 1980; Hedrick et al, 1984). Whereas differential screening is the choice when looking for abundantly expressed genes, the sensitivity for the detection of rare transcripts is very limited. This limit can be overcome, when subtractive hybridization or subtractive cloning is used for cell-culture experiments, but the complexity of tissues consisting of multiple cell-types restricts the detection of cell-type specific fragments. Furthermore, genes of interest may be expressed at low, but changing levels throughout all differentiation stages, making the choice of an appropriate subtraction-ratio extremely difficult. For example, apoptosis of cells may occur at a lower level even in non-involuting stages of the mammary gland (Ferguson and Anderson, 1981) and would lead to the subtraction of desired fragments from involuting stages. The Differential Display Assay (Liang and Pardee, 1992) offers a further commonly used strategy for the identification of differentially expressed genes and led to the characterization of many clones (Bauer et al, 1993; Liang et al, 1992; Sager et al, 1993). Using a modification of the original Differential Display protocol, an assay we call the 'Differential Display Coincidence Analysis' (DDC), we were able to compare directly the expression patterns of genes expressed in different tissues, but being involved in related processes, by displaying them in parallel on a gel. This led, in our study, to the identification of a variety of genes, potentially 
involved in apoptosis of both the mammary gland and the rat ventral prostate. Since cell death is hormone dependent in both the mammary gland and the prostate, studies involving DDC-analysis will also reveal apoptosis associated genes for which expression patterns are strictly hormone regulated in both tissues.

\section{The DDC genes and apoptosis}

The fact that clone DDC-3 shares greater than $90 \%$ homology with a segment located in the $3^{\prime}$ untranslated region of the mouse gas-1 RNA argues for its derivation from the rat gas-1 gene. Furthermore, using DDC-3 as a probe, we were not only able to detect a single transcript in mouse mammary gland RNAs corresponding with the published size of gas-1 (Schneider et al, 1988; Del Sal et al, 1992), but also were able to isolate exclusively mouse gas- 1 clones from a mouse mammary gland day 6 involution library (data not shown). Gas-1, a putative transmembrane protein bearing the RGDmotif of a potential integrin binding protein, has been shown to be transcriptionally strongly induced in NIH 3T3 cells under growth arrest caused either by serum starvation or contact inhibition. NIH 3T3 cells transfected with various viral oncogenes did not express gas-1 even after serum depletion and did not stop growing. Ectopic gas-1 expression in proliferating normal and the oncogene-transfected NIH 3T3 cells was able to induce growth inhibition. Since SV40 Large T antigen transfected cells failed to respond to gas-1 overexpression, it has been speculated, that gas- 1 is regulated by proteins like p53 or the retinoblastoma susceptibility protein (Del Sal et al, 1992; 1995). Recently, the chromosomal locus of human gas-1 has been linked to a region, which is frequently deleted in myeloid malignancies (Evdokiou et al, 1993). The signal is biphasic in the mammary gland, reproducibly declining at day 4 and returning strongly at day 6 in involution. This may hint at the loss of gas- 1 expressing epithelial cells by apoptosis and their replacement by a different gas-1 expressing population in late involution. gas-1 is clearly regulated by additional gene products as shown in the cycloheximide sensitivity experiment (Figure $7 \mathrm{~b}$ ). Furthermore, gas- 1 does not induce any cell cycle block in $\mathrm{G}_{1}$ (Figure $7 \mathrm{c}$ ), but seems to exert its function over several rounds of the cell cycle.

An increase of intracellular calcium concentrations has been linked to the activation of a specific DNA endonuclease-activity in nuclei of apoptotic cells (Wyllie, 1980; Cohen and Duke, 1984; Arends et al, 1990; Peitsch et al, 1993), which has been also detected in the involuting mammary gland as well as during ventral prostate regression. (Strange et al, 1992; Colombel et al, 1992). Furthermore, it has been shown that the application of calcium channel antagonists could markedly delay apoptosis in the ventral prostate after castration (Connor et al, 1988; Kyprianou et al, 1988). Thus, the high degree of homology between clone DDC-1 and the integrin-associated protein, a regulator of calcium influx (Brown et al, 1990; Lindberg et al, 1993; Schwartz et al, 1993), reflects a possible role for this molecule during PCD. More recent investigations of IAP point to a specific participation in collaboration with $\beta_{3}$-integrins, both in transendothelial migration of neutrophils (Cooper et al, 1995) and via an effect on $\beta_{1}$ integrins, on phagocytic activity by K562 cells (Blystone et al, 1995). The potential for IAP intervention in the apoptotic process is presently being investigated.

The similarity of clone DDC-2 with the sequence of AIF1 , a macrophage factor specifically regulated during rejection of cardiac allografts (Utans et al, 1995) and after carotid artery balloon angioplasty of rats (Autieri et al, 1995), points to its likely participation in cell death during the involution of the mammary gland and the ventral prostate. Interestingly, the CDNA encoding for AIF-1 was identified in both models by Differential Display (Autieri et al, 1995; Utans et al, 1994). Since the expression of AlF-1 has been studied by now solely under circumstances, which involve external damage to tissues, it will remain to be interesting learning about its role during non-necrotic, endogenously occurring cell death processes, i.e. during the removal of apoptotic cells.

Whereas DDC-5 displays an $80 \%$ homology with an expressed human sequence tag, sequence analysis of clone DDC-4 did not show homology with any known genes and its function has yet to be determined. Nevertheless, the fact that DDC-4 expression is not detectable in pre-involuting stages of the mammary gland and very weak in the normal prostate, is very interesting. Also the very rapid and transient increase of the DDC-4 signal at the time of onset of apoptosis in both tissues points to a very interesting role in involution, as does its dramatic oestrus-dependent expression, mainly detectable in the uterus.

We have presented a modified application for the Differential Display Assay (Liang and Pardee, 1992) which we call 'Differential Display Coincidence Analysis', allowing the detection of genes, regulated during related physiological processes in different tissues. The coincidence suggests that such genes are relevant for this process in general. Furthermore, we have presented evidence that genes regulated in coincidence during involution of the mammary gland and the prostate, are more likely to be linked with apoptosis than with tissue remodelling. With this protocol, we have been able to isolate several examples of coincidence. Precisely which cells are responsible for the expression of the genes described during mammary gland and prostate involution has still to be determined. Nevertheless, their strong regulation in both regressing tissues and the putative functions of the previously characterized homologues speaks for a probable apoptosis-associated function.

\section{Materials and Methods}

\section{Induction of involution in mammary and prostate glands}

Ventral prostate glands of mature male Sprague Dawley rats were removed from normal- and from 2, 4 and 6 day post-castration animals. Inguinal mammary glands derived from female rats of the same line representing virgin-, pregnant-, lactating- and different involutingstages after forced weaning were isolated. 


\section{RNA extraction, Northern blot analysis and differential display}

The guanidinium thiocyanate extraction protocol described by Chomczynski and Sacchi (1987) was used for total-RNA isolation from rat mammary and ventral prostate glands. PolyA(+)-enriched RNAs were prepared using oligo dT-cellulose (Boehringer Mannheim). Either $10 \mu \mathrm{g}$ of total RNA or $5 \mu \mathrm{g}$ poly(A)-enriched RNA/sample were loaded with glyoxal on a vertical $1 \%$ agarose gel in phosphate buffer, electrophoresed and blotted on nitrocellulose filters. Crosslinking was performed with UV-light using the Stratalinker 1800-device (Stratagene, La Jolla CA, USA). Filters were hybridized with random primed and $\left[{ }^{32} \mathrm{P}\right] \mathrm{dCTP}$ labeled fragments in $50 \%$ formamide, $4 \times$ SSC, $5 \times$ Denhardt's solution, $0.2 \%$ SDS, $0.1 \%$ sodium pyrophosphate and $30 \mu \mathrm{g} / \mathrm{ml}$ salmon sperm DNA at $42^{\circ} \mathrm{C}$ for $16 \mathrm{~h}$. Filters were washed twice at $42^{\circ} \mathrm{C}$ for $30 \mathrm{~min}$ in $2 \times \mathrm{SSC} / 0.2 \%$ SDS, followed by $0.1 \times$ $\mathrm{SSC} / 0.2 \%$ SDS at $60^{\circ} \mathrm{C}$. Filters were autoradiographed at $-70^{\circ} \mathrm{C}$ for appropriate times, using intensifier screens.

Hybridization-probes were: stromelysin (Matrisian et al, 1985); TIMP (Gewert et al, 1987); SGP-2 (Bandyk et al, 1990); tTG (Chiocca et al, 1988); TGF- $\beta 1$ (Derynck et al, 1985). The tPA-probe was the kind gift of $\mathrm{Dr}$ M. O'Connell and $\mathrm{DrN}$. Waller and a probe for the $72 \mathrm{kD}$ gelatinase was generously provided by $\mathrm{Dr} L$ Matrisian.

The 'RNAmap' - Kits A and B (GenHunter Corp., Brookline MA, USA) were used to amplify $0.2 \mu \mathrm{g}$ DNase I-treated total RNA from each sample as described in the manufacturers description. PCR reactions were run on $6 \%$ denaturing polyacrylamide/urea sequencing-gels, and exposed for 24 to $48 \mathrm{~h}$ on Kodak X-omat AR films. Bands of interest were excised from the gel and reamplified using the same primers (Table 1).

\section{Subcloning of PCR-fragments and DNA sequence analysis}

After reamplification, AmpliTaq-molecules bound to the PCRfragments were digested with proteinase $\mathrm{K}$ (Boehringer Mannheim) directly in the PCR-mixture. Remaining primers were eliminated over a Centricon-100 spin column (Amicon, Beverly MA, USA), the retentate phenolized and chloroform extracted. Precipitated and resolved PCRfragments were blunt-ended using Klenow-fragment (Boehringer) and kinased with T4 polynucleotide kinase (Boehringer) followed by the purification-step over 1\% low-melting-point agarose gels (Gibco BRL, Gaithersburg MD, USA). Blunt-end ligation was performed using T4 DNA-ligase (Boehringer) into the dephosphorylated Sma-1 sites of Bluescript plasmids (Stragagene). Ligated constructs were electroporated with the GenePulser (Bio-Rad, Hercules CA, USA) into XL-1 blue bacteria (Stratagene) and plated on LB/ampicilin plates containing X-gal/IPTG (Boehringer) to perform blue-white selection.

Cloned fragments were sequenced on both strands using the dideoxynucleotide chain termination method performed with the Sequenase 2.0 kit (USB, Cleveland OH, USA). Sequence analysis was performed by comparing with the EMBL-Databank or GenebankDatabase.

\section{In situ Hybridization}

Bluescript (Stratagene) constructs were used to prepare riboprobes in sense and anti-sense directions for DDC-1 (IAP) and DDC-3 (gas-1). For $D D C-1$, a full-length clone was employed for in vitro transcription, after which transcripts were fragmented by alkaline hydrolysis to a length of approximately 200 bases. For $D D C-3$, a subclone extending from base 1261 until the $3^{\prime}$ end was isolated and employed to prepare sense and antisense riboprobes similarly hydrolyzed. The transcrip- tion reactions were performed with fluorescein-11-dUTP (Amersham International, Little Chalfont, England). Tissue samples were fixed for $16 \mathrm{~h}$ in freshly prepared $4 \%$ formaldehyde (paraformaldehyde) in phosphate buffered saline at $0^{\circ} \mathrm{C}$. Embedding was in paraffin at $56^{\circ} \mathrm{C}$. After sectioning, pre-treatments included proteinase $\mathrm{K}$ as above, followed by $5 \mathrm{~min}$ postfixation with $4 \%$ formaldehyde at $0^{\circ} \mathrm{C}, 0.02 \mathrm{M}$ $\mathrm{HCl}\left(5 \mathrm{~min}\right.$ in water at $22^{\circ} \mathrm{C}$ ) and acetylation using conventional protocols. Prehybridization and hybridization were performed in the presence of $50 \%$ formamide in $2 \times \mathrm{SSC}$ at $50^{\circ} \mathrm{C}$. Hybridization was carried out for $16 \mathrm{~h}$, followed by washing in 50\% formamide in $2 \times$ SSC at $50^{\circ} \mathrm{C}$ and washes up to $60^{\circ} \mathrm{C}$ with $0.1 \times \mathrm{SSC}$. Alkaline phosphataseconjugated anti-FITC Fab fragments (Amersham) were finally used for detection.

\section{Acknowledgements}

We thank Drs Anne-Catherine Andres and Andrew Ziemiecki for many valuable discussions and for comments to the manuscript. This work was supported by research grants from the Cancer League of Berne, the Stiftung für klinisch-experimentelle Tumorforschung, and the Swiss National Science Foundation to RR Friis and A-C Andres, No. 3142433.94. This work was presented in partial fulfilment of the requirements for the doctoral degrees of WB and GK.

\section{References}

Arends MJ, Morris RG and Wyllie AH (1990) The role of the endonuclease. Amer. J. Pathol. 136: 593-608

Autieri MV, Feuerstein GZ, Yue TL, Ohlstein EH and Douglas SA (1995) Use of Differential Display to identify differentially expressed mRNAs induced by rat carotid artery balloon angioplasty. Laborat. Invest. 72: 656-661

Bandyk MG, Sawzuk IS, Olson CA, Katz AE and Buttyan R. (1990) Characterization of the products of a gene expressed during androgen-programmed cell death and their potential use as a marker of urogenital injury. J. Urol. 143: 407-412

Bauer D, Müller H, Reich J, Riedel H, Ahrenkiel V, Warthoe P and Strauss M (1993) Identification of differentially expressed mRNA species by an improved display technique (DDRT-PCR). Nucleic Acids Res. 21: 4272-4280

Bielke W, Ke G, Strange R and Friis RR (1995) Apoptosis in mouse mammary gland involution: isolation and characterization of apoptosis-specific genes. In: CJ Wilde, M Peaker and CH Knight (eds), Intercellular Signalling in the Mammary Gland. Plenum Press, New York, pp 45-55

Blystone SD, Lindberg FP, LaFlamme SE and Brown EJ (1995) Integrin $\beta_{3}$ cytoplasmic tail is necessary and sufficient for regulation of the $\alpha_{5} \beta_{1}$ phagocytosis by $\alpha_{v} \beta_{3}$ and integrin-associated protein. J. Cell Biol. 130:745-754

Brown E, Hooper L, Ho T and Gresham H (1990) Integrin Associated Protein: A 50-kD plasma membrane antigen physically and functionally associated with integrins. J. Cell Biol. 111: 2785-2794

Buttyan R, Olsson CA, Pintar J, Chang C, Bandyk M, Ng P-Y and Sawczuk IS (1989) Induction of the TRPM-2 gene in cells undergoing programmed death. Mol. Cell. Biol. 9: 3473-3481

Chiocca EA, Davies JA and Stein JP (1988) The molecular basis of retinoic acid action. J. Biol. Chem. 263: 11584-11589

Chomczynski $P$ and Sacchi N (1987) Single-step method of RNA isolation by guanidinium thiocyanate-phenol-chloroform extraction. Anal. Biochem. 162: $156-159$

Cohen JJ and Duke RC (1984) Glucocorticoid activation of a calcium-dependent endonuclease in thymocyte nuclei leads to cell death. J. Immunology 132: 38 42

Colombel M, Olsson CA, Ng P-Y and Buttyan R (1992) Hormone-regulated apoptosis results from reentry of differentiated prostate cells onto a defective cell cycle. Cancer Res. 52: 4313-4319

Connor J, Sawczuk IS, Benson MC, Tomashefsky P, O'Toole KM, Olsson CA and Buttyan R (1988) Calcium channel antagonists delay regression of androgendependent tissues and suppress gene activity associated with cell death. The Prostate 13: $119-130$ 
Cooper D, Lindberg FP, Gamble JR, Brown EJ and Vadas MA (1995) Transendothelial migration of neutrophils involves integrin-associated protein (CD47). Proc. Natl. Acad. Sci. USA 92: 3978-3982

Daniel CW and Silberstein GB (1987) Postnatal development of the rodent mammary gland. In: The mammary gland development, regulation and function, (MC Neville and CW Daniel. Plenum Press, New York and London,pp. 3-36

Del Sal G, Ruaro EM, Philipson L and Schneider C (1992) The growth arrest-specific gene gas1, is involved in growth suppression. Cell 70:595-607

Del Sal G, Ruaro EM, Utrera R, Cole CN, Levine AJ and Schneider C (1995) GAS1induced growth suppression requires a transactivation-independent p53 function. Mol. Cell Biol. 15: 7152-7160

Derynck R, Jarrett JA, Chen EY, Eaton DH, Bell JR, Assoian RK, Roberts AB, Sporn $M B$ and Goeddel DV (1985) Human transforming growth factor $\beta$ complementary DNA sequence and expression in normal and transformed cells. Nature 316 : $701-705$

Dickson SR and Warburton MJ (1992) Enhanced synthesis of gelatinase and stromelysin by myoepithelial cells during involution of the rat mammary gland. J. Histochem. Cytochem. 40: 697-703

Donehower LA and Bradley A (1993) The tumor suppressor p53. Biochim. Biophys. Acta 1155: 181-205

El-Deiry WS, Tokino T, Velculescu VE, Levy DB, Parsons R, Trent JM, Lin D, Mercer E, Kinzler KW and Vogelstein B (1993) WAF1, a potential mediator of p53 tumor suppression. Cell 75: $817-825$

Evdokiou A, Webb GC, Peters GB, Dobrovic A, O'Keefe DS, Forbes IJ and Cowled PA (1993) Localization of the human growth arrest-specific gene (Gas1) to chromosome bands 9q21.3-q22, a region frequently deleted in myeloid malignancies. Genomics 18: $731-733$

Ferguson DJP and Anderson TJ (1981) Ultrastructural observation on cell death by apoptosis in the "resting" human breast. Virchows Arch. A 393: 193-203

Fesus L, Thomazy V and Falus A (1987) Induction and activation of tissue transglutaminase during programmed cell death. FEBS 224: 104-108

Gavrieli Y, Sherman Y and Ben-Sasson SA (1992) Identification of programmed cell death in situ via specific labeling of nuclear DNA fragmentation. J. Cell Biol. 119: 493-501

Gewert DR, Coulombe B, Castellino M, Skup D and Williams BRG (1987) Characterization and expression of a murine gene homologous to human EPA/TIMP: A virus-induced gene in the mouse. EMBO J. 6: 651-657

Guenette RS, Corbeil HB, Léger J, Wong K, MézI V, Mooibroek M and Tenniswood M (1994) Induction of gene expression during involution of the lactating mammary gland of the rat. J. Mol. Endocrinology 12: 47-60

Harper JW, Adami GR, Wei N, Keyomarsi K and Elledge SJ (1993) The p21 Cdkinteracting protein $\mathrm{Cip} 1$ is a potent inhibitor of $\mathrm{G} 1$ cyclin-dependent kinases. Cell 75: $805-816$

Hedrick SM, Cohen DI, Nielsen EA and Davis MM (1984) Isolation of cDNA clones encoding T cell-specific membrane-associated proteins. Nature 308: 149-153

Itoh N, Yonehara S, Ishii A, Yonehara M, Mizushima SJ, Sameshima M, Hase A, Seto $Y$ and Nagata S (1991) The polypeptide encoded by the cDNA for human cell surface antigen Fas cam mediate apoptosis. Cell 66: 233-243

Jehn BM and Osborne BA (1997) Gene regulation associated with apoptosis. Crit. Rev. Eukaryot. Gene Expression. In press

Jenne DE and Tschopp J (1992) Clusterin: the intriguing guises of a widely expressed glycoprotein. TIBS 17: 154-159

Kastan MB, Zhan Y, El-Deiry WS, Carrier F, Jacks T, Walsh WV, Plunkett BS Vogelstein B and Fornace AJ Jr. (1992) A mammalian cell cycle checkpoint pathway utilizing p53 and GADD45 is defective in Ataxia-Telangiectasia. Cell 71: $587-597$

Kerr JFR and Searle J (1973) Deletion of cells by apoptosis during castration-induced involution of the rat prostate. Virchows Arch. B 13: 87-102

Kerr JFR, Wyllie AH and Currie AR (1972) Apoptosis: a basic biological phenomenon with wide-ranging implications in tissue kinetics. Br. J. Cancer 26: 239-257

Kuerbitz SJ, Plunkett BS, Walsh WV and Kastan MB (1992) Wild-type p53 is a cell cycle checkpoint determinantfollowing irradiation. Proc. Natl. Acad. Sci. USA 89: $7491-7495$

Kumar S, Kinoshita M, Noda M, Copeland NG and Jenkins NA (1994) Induction of apoptosis by the mouse Nedd2 gene, which encodes a protein similar to the product of Caenorhabditis elegans cell death gene ced-3 and the mammalian IL1b-converting enzyme. Genes and Dev. 8: 1613-1626
Kyprianou N, English HF and Isaacs JT (1988) Activation of a Ca ${ }^{2+}-\mathrm{MG}^{2+}$-dependent endonuclease as an early event in castration-induced prostatic cell death. The Prostate 13: 103-117

Li F, Bielke W, Guo K, Andres A-C, Jaggi R, Friis RR, Niemann H, Bernis L, Geske FJ and Strange $\mathrm{R}$ (1995) Isolation of cell death associated cDNAs from involuting mouse mammary epithelium. Cell Death and Diff. 2: 113-122

Liang P and Pardee AB (1992) Differential Display of eukaryotic messenger RNA by means of the Polymerase Chain Reaction. Science 257: 967-971

Liang P, Averboukh L, Keyomarsi K, Sager R and Pardee AB (1992) Differential Display and cloning of messenger RNAs from human breast cancer versus mammary epithelial cells. Cancer Res. 52: 6966-6968

Lin D, Shields MT, Ullrich SJ, Appella E and MercerWE (1992) Growth arrest induced by wild-type 53 protein blocks cells prior to or near the restriction point in late $\mathrm{G} 1$ phase. Proc. Natl. Acad. Sci. USA 89: 9210-9214

Lindberg FP, Gresham HD, Schwarz E and Brown EJ (1993) Molecular cloning of Integrin-Associated Protein: an immunoglobulin family member with multiple membrane-spanning domains implicated in $\beta_{3}$-dependent ligand binding. J. Cell Biol. 123: 485-496

Liu Z-G, Smith SW, McLaughlin KA, Schwartz LM and Osborne BA (1994) Apoptotic signals delivered through the T-cell receptor of a T-cell hybrid require the immediate-early gene nur77. Nature 367: 281-284

Lockshin RA and Williams CM Programmed Cell Death-II. (1964) Endocrine potentiation of the breakdown of the intersegmental muscles of silkmoths. J. Ins. Physiol. 10: 643-649

Lund LR, Romer J, Thomasset N, Solberg H, Pyke C, Bissel MJ, Dano K and Werb Z (1996) Two distinct phases of apoptosis in mammary gland involution: proteinase-independent and dependent pathways. Development 122: 181-193

Marti A, Jehn B, Costello E, Keon N, Ke G, Martin F and Jaggi R (1994) Protein kinase $A$ and AP-1 (c-Fos/JunD) are induced during apoptosis of mouse mammary epithelial cells. Oncogene 9: 1212-1223

Martikianen P, Kyprianou N and Issacs JT (1990) Effect of Transforming Growth Factor- $\beta 1$ on proliferation and death of rat prostatic cells. Endocrinology 127 $2963-2968$

Matrisian LM, Glaichenhaus N, Gesnel M-C and Breathnach R (1985) Epiderma growth factor and oncogenes induce transcription of the same cellular mRNA in rat fibroblasts. EMBO J. 4: 1435-1440

McConkey DJ, Hartzell P, Nicotera P and Orrenius S (1989) Calcium-activated DNA fragmentation kills immature thymocytes. Faseb J. 3: 1843-1849

Miura M, Zhu H, Rotello R, Hartwieg EA and Yuan J (1993) Induction of apoptosis in fibroblasts by IL-1 beta-converting enzyme, a mammalian homolog of the $C$. elegans cell death gene ced-3. Cell 75: 653-660

Miyashita T and Reed JC (1995) Tumor suppressor p53 is a direct transcriptional activator of the human bax Gene. Cell 80: 293-299

Nelson WG and Kastan MB (1994) DNA strand breaks: the DNA template alterations that trigger p53-dependent DNA damage response pathways. Mol. Cell. Biol. 14: $1815-1823$

Peitsch MC, Polzar B, Stephan H, Crompton T, MacDonald HR, Mannherz HG and Tschopp J (1993) Characterization of the endogenous deoxyribonuclease involved in nuclear DNA degradation during apoptosis (programmed cell death). EMBO J. 12: $371-377$

Pitelka DR (1988) The mammary gland. In: Cell and Tissue Biology, (ed. L Weiss) pp. 877-898, Baltimore, Urban and Schwarzenberg

Rotello RJ, Lieberman RC, Purchio AF and Gerschenson LE (1991) Coordinated regulation of apoptosis and cell proliferation by transforming growth factor $\beta 1$ in cultured uterine epithelial cells. Proc. Natl. Acad. Sci. USA 88: 3412-3415

Ryan JJ, Danish R, Gottlieb CA and Clarke MF (1993) Cell cycle analysis of p53induced cell death in murine erythroleukemia cells. Mol. Cell. Biol. 13: 711-719

Sager R, Anisowicz A, Neveu M, Liang P and Sotiropoulou G (1993) Identification by Differential Display of alpha 6 integrin as a candidate tumor suppressor gene. FASEB J. 7: 964-970

Schneider C, King RM and Philipson L (1988) Genes specifically expressed at growth arrest of mammalian cells. Cell 54: 787-793

Schwartz LM, Milligan CE, Bielke W and Robinson SJ (1995) Cloning cell death genes. In: Methods in Cell Biology; Cell Death. (eds.: LM Schwarz and BA Osborne) 46: 107-138, New York, N.Y. Academic Press 
Schwartz MA, Brown EJ and Fazeli B (1993) A 50-kDa integrin-associated protein is required for integrin-regulated calcium entry in endothelial cells. J. Biol. Chem. 268: $19931-19934$

Shaw P, Bovey R, Tardy S, Sahli R, Sordat B and Costa J (1992) Induction of apoptosis by wild-type p53 in human colon tumor-derived cell line. Proc. Natl. Acad. Sci. USA 89: 4495-4499

St. John TP and Davis RW (1979) Isolation of galactosidase-inducible DNA sequences from Saccharomyces cerevisiae by differential plaque filter hybridization. Cell 16: $443-449$

Strange R, Li F, Saurer S, Burkhardt A and Friis RR (1992) Apoptotic cell death and tissue remodelling during mouse mammary gland involution. Development 115 : $49-58$

Suda T, Takahashi T, Goldstein P and Nagata S (1993) Molecular cloning and expression of the Fas ligand, a novel member of the tumor necrosis factor family. Cell 75: $1169-1178$

Talhouk RS, Bissell MJ and Werb Z (1992) Coordinated expression of extracellular matrix-degrading proteinases and their inhibitors regulates mammary epithelial function during involution. J. Cell Biol. 118: 1271-1282

Tenniswood MP, Guenette RS, Lakins J, Mooibroek M, Wong P and Welsh J-E (1992) Active cell death in hormone-dependent tissues. Cancer Metastasis Rev. 11: $197-220$

Trauth BC, Klas C, Peters AMJ, Matzku S, MollerP, FalkW, Debatin KMand Krammer $\mathrm{PH}$ (1989) Monoclonal antibody-mediated tumor regression by induction of apoptosis. Science 245: 301-305

Utans U, Arceci RJ, Yamashita Y and Russell ME (1995) Cloning and characterization of Allocraft Inflammatory Factor-1: a novel macrophage factor identified in rat cardiac allografts with chronic rejection. J. Clin. Invest. 95:2954 2962

Utans U, Liang P, Wyner LR, Karnovsky MJ and Russell ME (1994) Chronic cardiac rejection: identification of five upregulated genes in transplanted hearts by differential mRNA display. Proc. Natl. Acad. Sci USA. 91: 6463-6467
Walker NI, Bennett RE and Kerr JFR (1989) Cell death by apoptosis during involution of the lactating breast in mice and rats. Am. J. Anatomy 185: 19-32

Wang L, Miura M, Bergeron L, Zhu H and Yuan Y (1994) Ich-1, an ICE/ced-3 related gene, encodes both positive and negative regulators of programmed cell death. Cell 78: $739-750$

Warburton MJ, Mitchell D, Ormerod EJ and Rudland P (1982) Distribution of myoepithelial cells and basement membrane proteins in the resting, pregnant, lactating and involuting rat mammary gland. J. Histochem. Cytochem. 30:667676

Williams JG and Lloyd MM (1979) Changes in the abundance of polyadenylated RNA during slime mold development measured using cloned molecular hybridization probes. J. Mol. Biol. 129: 19-25

Woronicz JD, Calnan B, Ngo V and Winoto A (1994) Requirement for the orphan steroid receptor Nur77 in apoptosis of T-cell hybridomas. Nature 367: 277-281

Wyllie AH (1980) Glucocorticoid-induced thymocyte apoptosis is associated with endogenous endonuclease activation. Nature 284: $555-556$

Wyllie AH, Kerr JFR and Currie AR (1980) Cell death: The significance of apoptosis. Int. Rev. Cytol. 68: 251-306

Yonish-Rouach E, Resnitzky D, Lotem J, Sachs L, Kimchi A and Oren M (1991) Wildtype p53 induces apoptosis of myeloid leukaemic cells that is inhibited by interleukin-6. Nature 352: 345-34

Yuan J, Shahan S, Ledoux S, Ellis HM and HorvitzHR(1993) The c-elegans cell death gene ced-3 encodes a protein similar to mammalian interleukin 1-converting enzyme. Cell 75: 641-652

Zimmermann CR, Orr WC, Leclerc RF, Barnard EC and Timberlake WE (1980) Molecular cloning and selection of genes regulated in Aspergillus development. Cell 21: $709-715$ 